\title{
Paradox pulzus
}

\author{
Zöllei Éva dr. - Rudas László dr.
}

Szegedi Tudományegyetem, Általános Orvostudományi Kar, Aneszteziológiai és Intenzív Terápiás Intézet, Szeged

\begin{abstract}
A perifériás pulzus tapintása évezredeken keresztül az orvosok egyetlen eszköze volt a keringés megítélésére. A pulzus frekvenciájának, amplitúdójának és mintázatának vizsgálata olyan megfigyeléseket tett lehetővé, melyeket a modern orvostudomány gyakran megerősít, és igyekszünk a kórfolyamatokat pontosan feltárni. A klasszikus megfigyelések egyike a paradox pulzus (PP), mely eltéró kórállapotokban potenciálisan életveszélyes állapotokra, asztmás rohamra, pericardialis tamponádra vagy súlyos hypovolaemiára hívhatja fel a figyelmet. Összefoglalónkban bemutatjuk a PP magyarázatát, és szemléltetjük azt is, hogy miként értelmezhető a jelenség a modern orvosi eszközök világában. Orv Hetil. 2020; 161(38): 1629-1635.
\end{abstract}

Kulcsszavak: paradox pulzus, asztma, pericardialis tamponád, hypovolaemia, systolésnyomás-változás

\section{Paradoxical pulse}

For thousands of years, palpation of the peripheral pulse was the most important source of information for the physicians about their patients' circulation. The rate, amplitude, and pattern of the pulse served as a basis of amazing observations, although several of them have been also confirmed and substantiated by modern medicine. One of the classical signs is "paradoxical pulse" (PP), which signals potentially life-threatening conditions with various mechanisms in certain diseases. In our review, we demonstrate the pathophysiological bases of PP, and show the equivalents of this sign provided by modern medical equipments.

Keywords: paradoxical pulse, asthma, pericardial tamponade, hypovolemia, systolic pressure variation

Zöllei É, Rudas L. [Paradoxical pulse]. Orv Hetil. 2020; 161(38): 1629-1635.

(Beérkezett: 2020. március 30.; elfogadva: 2020. április 27.)

\section{Rövidítések}

COPD $=$ (chronic obstructive pulmonary disease $)$ krónikus obstruktív tüdőbetegség; MSFP = (mean systemic filling pressure) átlagos szisztémás töltőnyomás; $\mathrm{PP}=$ paradox pulzus; $\mathrm{PPV}=$ (pulse pressure variation) pulzusnyomás-változás; SPV $=$ (systolic pressure variation) systolésnyomás-változás; SVV = (stroke volume variation) verőtérfogat-változás

\section{A paradox pulzus fogalma, története}

$\mathrm{Az}$ orvostudomány a kezdetektől fogva nagy figyelmet szentelt a pulzus tapintással végzett vizsgálatának. Az ókori egyiptomiak, mezopotámiaiak, kínaiak, görögök és rómaiak, majd a középkori arab orvosok számára a pulzus jelentette az egyetlen ablakot, melyen keresztül pillantást vethettek a keringésre $[1,2]$. Az egyszerú módszer az évszázadok során csodálatra méltó megfigyelésekhez vezetett. Így egy XVII. századi angol orvos, Richard Lower érdekes megállapítást tett constrictiv pe- ricarditisben szenvedő betegén. Észrevette, hogy a páciens pulzusa nemcsak gyenge, hanem intermittáló jellegú. A megfigyelést a szívburok és a rekesz összenövéseivel, illetve a belégzéskor lefele mozduló rekesz szívet vongáló, így azt múködésében gátló hatásával magyarázta [3]. Még mindig az egyszerű fizikális diagnosztikára támaszkodva írta le Adolf Kussmaul 1873-ban négy (közülük egy ugyancsak pericardialis constrictióban szenvedó) betegen végzett megfigyelését, miszerint a tapintható pulzus gyenge és „irreguláris”, azaz eltünik belégzéskor és visszatér kilégzés alatt $[4,5]$. Megfigyelte azt is, hogy eközben folyamatosan észlelhető a szívcsúcslökés, és ezért úgy vélte - logikus következtetésként -, hogy a pulzus belégzési eltúnése paradox jelenség. Kussmaultól származik a „paradox pulzus” (PP) kifejezés [4]. Igaz - mint majd látjuk -, hogy nem annyira paradox, mint inkább kórosan fokozott légzési vérnyomásválaszról van szó. Számos kutató - így többek közt Sommerbrodt 1877-ben [6] és Thomas Lewis 1908-ban [7] - megálla- 
pította, hogy a légzési pulzus fluktuációja egészséges alanyokban is megfigyelhetó, így a PP egyfajta téves megnevezés. Tény azonban, hogy a PP kifejezés az orvosi nyelvben tartósan meggyökeresedett, s közel 150 év elteltével kár lenne elvetni használatát. Mind Lower, mind Kussmaul noninvazív eszközökre támaszkodott; az első valódi, invazív artériás nyomásmérést Stephan Hales tiszteletes végezte híres állatkísérletében 1733-ban, s egyúttal észlelte a légzés vérnyomásra gyakorolt hatásait is [8]. Az invazív nyomásmérés későbbi lassú elterjedése és a keringésmonitorozás egyéb eszközeinek megjelenése azután emberekben is lehetővé tette a légzés és a keringés kölcsönhatásainak tanulmányozását.

A belégzési systolés vérnyomás esése normálisan 10 Hgmm alatti, de ezt egészségesekben is számos tényező befolyásolja. A légzési systolés nyomás normális (tehát nem akaratlagosan eróltetett) ingadozása 3-5 Hgmm körüli, definíciószerúen a 10-12 Hgmm-t meghaladó ingadozást nevezzük PP-nak. Dornhorst és mtsai 1952 ben közölték alapvető következtetéseiket, melyeket 50, egészséges keringésű alanyban készített regisztrátumaik analíziséből vontak le [9]. Megállapították, hogy a légzési fázisok és a vérnyomásváltozás közti kapcsolódások légzésszámfüggőek. Míg normális légzésszám mellett a belégzést többnyire vérnyomásesés kíséri, lassú légzéskor a belégzés vérnyomás-emelkedéssel jár. Ugyancsak megállapították, hogy a lassú légzés nagyobb amplitúdójú vérnyomásváltozást generál. További megfigyelésük volt, hogy felegyenesedett testhelyzetben a vérnyomás-fluktuációk ugyancsak felerősödnek [9]. Dornhorsték közleményét utóbb számos további megfigyelés követte, s a folyamatokat pontosan tudjuk magyarázni: megértésükhöz végig kell követnünk a vér útját a perifériás vénás kapillárisoktól a jobb szívfélig, majd tovább a pulmonalis keringésen és a bal szívfélen át.

\section{A légzés keringési hatásai egészséges alanyokban, normális légzés során}

Egészséges emberben a belégzés csökkenti a jobb pitvari nyomást, ezzel megnő a perifériás vénás végpont, azaz az átlagos szisztémás töltőnyomás (mean systemic filling pressure, MSFP) és a jobb pitvar közti nyomásgradiens. İgy megnő a vénás visszaáramlás is, és a normálisan „preload irányított” jobb kamra növekvő verő- és perctérfogatot továbbít. Emlékeznünk kell arra, hogy a vena cava intrathoracalis szakasza szelepszerúen múködik: bizonyos negatív nyomásnál összeesik, és a visszaáramlás már nem fokozható. A jobb kamra, csakúgy, mint a pulmonalis artériák transmuralis nyomása belégzésben megnő. Ezzel szemben a kis alveolaris erek környezetében belégzés végén a nyomás közel atmoszferikus [10]. Az ekképp kissé növekedő utóterhelést normális légzés során az egyébként „utóterhelés-érzékeny” jobb kamránk még jól tolerálja. Visszatérve a belégzéssel megnövekedő jobb kamrai verőtérfogathoz, ez szükségszerüen megnövekedett visszaáramláshoz vezet a bal szívfél felé. Ez a „soros kapcsolódású interdependencia” néhány szívciklusnyi késlekedéssel érvényesül, és egészséges alanyok normális légzésekor alapvetően ez határozza meg a bal kamrai verőtérfogat és a vérnyomás hullámzását. Mély, különösen forszírozott belégzésben a tágulékony pulmonalis vénás rendszerben raktározás (pooling) figyelhető meg, ez ugyancsak hozzájárulhat a légzési vérnyomás ingadozásainak amplitúdónövekedéséhez. A bal kamra transmuralis nyomásában bekövetkező normális belégzési változás nem jelent a kamra számára számottevő utóterhelés-növekedést, s feltehetőleg nem játszik vezető szerepet a légzési vérnyomáshullámzásban. Megjegyzendő, hogy zárt glottisszal szemben végzett eróltetett akaratlagos belégzési kísérletnél (Müller-manőver) extrém negatív nyomásértékeket lehet elérni, egész -140 $\mathrm{cmH}_{2} \mathrm{O}$-ig [11]. Ez a faktor már egészséges emberekben is jelentősen befolyásolhatja a bal kamra múködését [12], és bizonyos kórállapotokban valóban szerepet játszik. A két kamra közös térben, a pericardiumzsákban helyezkedik el, normális körülmények között azonban az egymásra gyakorolt közvetlen hatás („parallel kamrai interdependencia”) szerepe nem jelentős, a fentiekben részletezett soros kapcsolásból származó hatások dominálnak [10].

\section{A kóros, (paradox) pulzus válasz tényezői}

Elsóként, a számos kapcsolódó mechanizmusra való tekintettel, a forszírozott légzés szerepét kell áttekintenünk. Az erőltetett, forszírozott légzésről asztmás roham, illetve a COPD-exacerbatio jut eszünkbe, mint a PP-sal járó állapotok iskolapéldái [13]. A PP mechanizmusa azonban ezekben a kórképekben nagyon összetett. A klinikai vizsgálatokban az intrathoracalis belégzési nyomás lényegesen kisebb csökkenését találták annál, mint amit a fent leírt akaratlagos Müller-manővereknél láttunk. Az intrathoracalis nyomás ingadozása sem spontán jelentkező asztmás roham [14, 15], sem hideg levegővel folytatott isocapniás hyperventilatiós provokációs teszt során [13] nem haladta meg a 30 Hgmm-t. Valójában ez is számottevően meghaladja a normális légzési ingadozást, és a jobb kamra utóterhelésének ciklikus növekedésén keresztül hozzájárulhat az artériás paradox pulzushoz [15]. A forszírozott légzés növeli a belégzési pulmonalis vénás raktározást, és számos további következménnyel jár. Az abdominalis nyomás növekedésén keresztül növeli a vénás visszaáramlást vezérlő nyomást is. Ugyanakkor, mint már utaltunk rá, a forszírozott légzéssel járó negatív intrathoracalis nyomás a vena cava inferior záródásához vezethet. Azt, hogy a forszírozott légzés melyik hatása fog dominálni (abdominalis vagy intrathoracalis), a vena cava töltöttségén s így záródási nyomásán keresztül a volumenviszonyok határozhatják meg. Hypervolaemiában a fokozott visszaáramlás, hypovolaemiában a csökkent visszaáramlás irányába hathat a forszírozott légzés $[10,16]$. A vénás visszaáramlás növekedése asztmás rohamban elérhet olyan szintet, hogy a 
telődő jobb kamra már gátolja a bal kamra telődését. A két kamra közti kompetíciót, a parallel interdependencia kóros fokozódását hemodinamikai és echokardiográfiás vizsgálatok is bizonyították [15]; jelenleg ezt tekintjük az asztmás rohamhoz társuló PP fó mechanizmusának [10]. Az 1. ábrán asztmás kórelőzményű, heveny légzési elégtelenséggel hospitalizált betegünk felvételét mutatjuk be.

Meg kell jegyeznünk, hogy bár a negatív intrathoracalis nyomás asztmás rohamban nem ér el extrém szinteket, ismerünk olyan kóros helyzeteket, amikor ez valóban megtörténik. Előfordul pillanatszerúen és epizodikusan obstruktív alvási apnoéban [17], továbbá elhúzódóbban átmeneti felső légúti obstrukció során. $\mathrm{Az}$ utóbbihoz kötődő negatív nyomású tüdőödéma egyik mechanizmusa a bal kamrai utóterhelés fokozódása és az ebből fakadó balkamra-diszfunkció [11].

Az asztmás rohamban a PP összetett mechanizmusa sok szálon kötődik a forszírozott légzéshez. Pericardialis tamponádban eltérő a helyzet, már a korai beszámolók egyetértettek abban, hogy ilyenkor az eróltetett légzésnek nincs szerepe $[18,19]$. A tamponád kialakulását a leghelyesebb a növekvő pericardialis folyadékhoz, illetve nyomáshoz kapcsolódó folyamatnak tekinteni, melynek végpontját jelenti a keringés-összeomlás [20]. A pericar- dialis tamponád kialakulása és a folyamat echokardiogáfiával dokumentálható fázisainak bemutatása meghaladná jelen kéziratunk kereteit, az alábbiakban a PP-sal összefüggő tényezőkre koncentrálunk. A normálisan negatív értékű intrapericardialis nyomás hullámzásait az intrathoracalis nyomás és a szívüregek összvolumenének változásai vezérlik. A pericardialis folyadék szaporodása az intrapericardialis nyomás növekedéséhez vezet. Saját akut kompenzálómechanizmusunk a szimpatikus aktivitás fokozásával a vascularis tónusnak, így a MSFP-nak a növelése, de ez a válasz véges. Krónikus folyamatban adaptációként a folyadékretenció is emeli a MSFP-t, de ilyenkor maga a pericardium is adaptálódik, és az intrapericardialis nyomás lassabban éri el a kritikus értéket [21]. A helyzet akkor válik veszélyessé, amikor az intrapericardialis nyomás $20 \mathrm{Hgmm}$ körüli értéken kiegyenlítődik a pitvari nyomásokkal, s együtt emelkedve gátolják a vénás visszaáramlást. A csökkenő vénás visszaáramlás csökkenő bal kamrai verőtérfogathoz, perctérfogathoz, elégtelen koszorúér-perfúzióhoz, majd keringési katasztrófához vezet [20]. A PP-t a kórképben régebben késői jelnek tekintették, ma már tudjuk, hogy korábbi fázisokban is megjelenhet [21]. Létrejöttében két faktor játszhat szerepet - mindkét mechanizmust felvetették már a korai magyarázatok is. Az egyik magyarázat abból indul
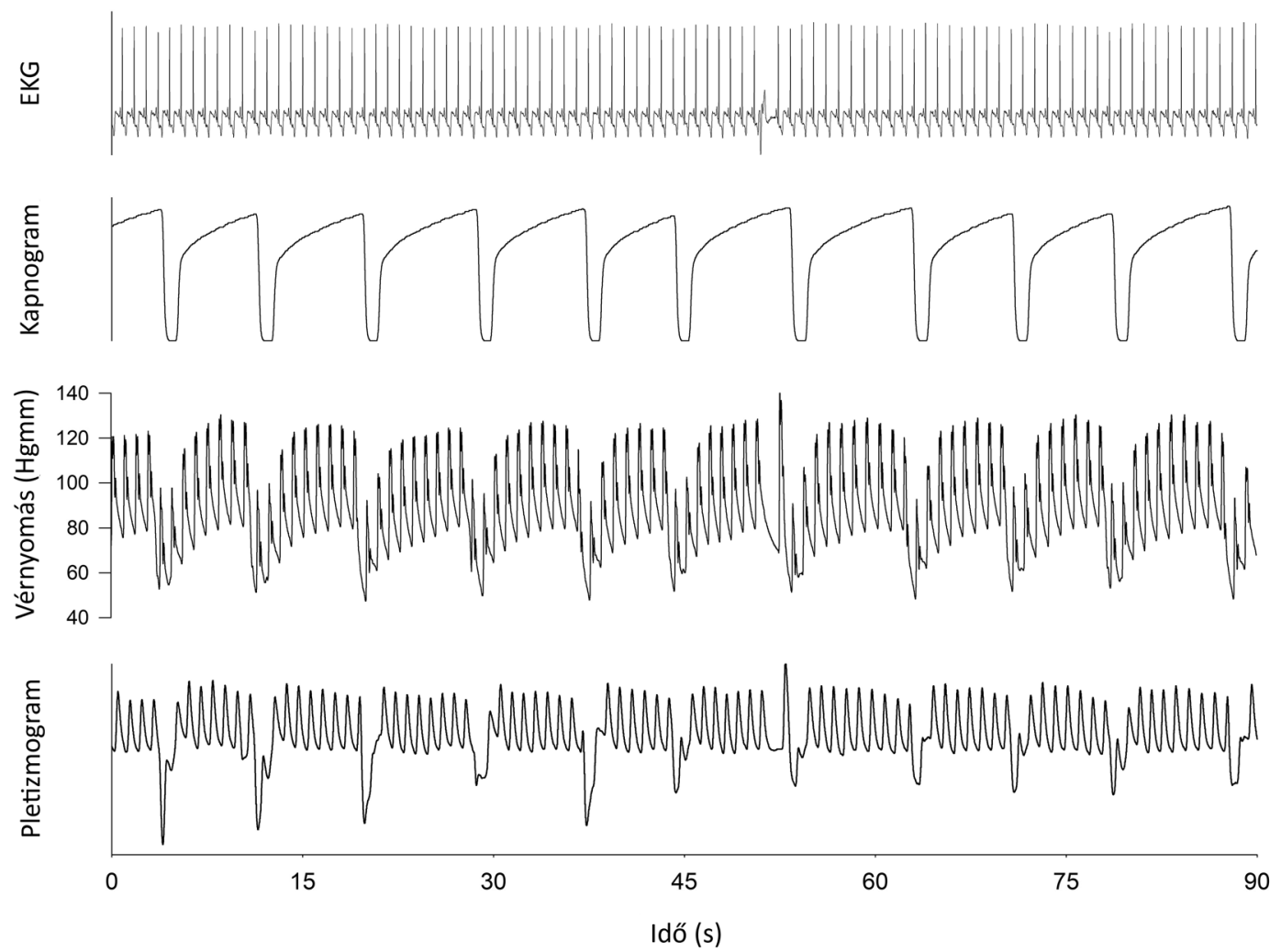

1. ábra

\footnotetext{
Asztmás kórelőzményű, heveny légzési elégtelenséggel hospitalizált, géppel lélegeztetett betegünk felvétele. A jeleket a Nihon Kohden (Tokió, Japán) által gyártott MU-671RK típusjelú betegórző monitor szinkrón pontjáról vezettük el, és csatornánként 250 Hz-es frekvenciával digitalizáltuk. (A további ábrák felvételeit ugyanígy rögzítettük.) Az ábra paneljei felülről lefelé haladva az EKG-t, a kapnogramot, az artériás nyomást és a pulzoximéter által szolgáltatott fotopletizmogramot mutatják be

$\mathrm{EKG}=$ elektrokardiográfia
} 
A

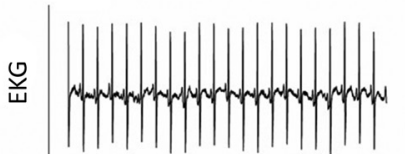

B
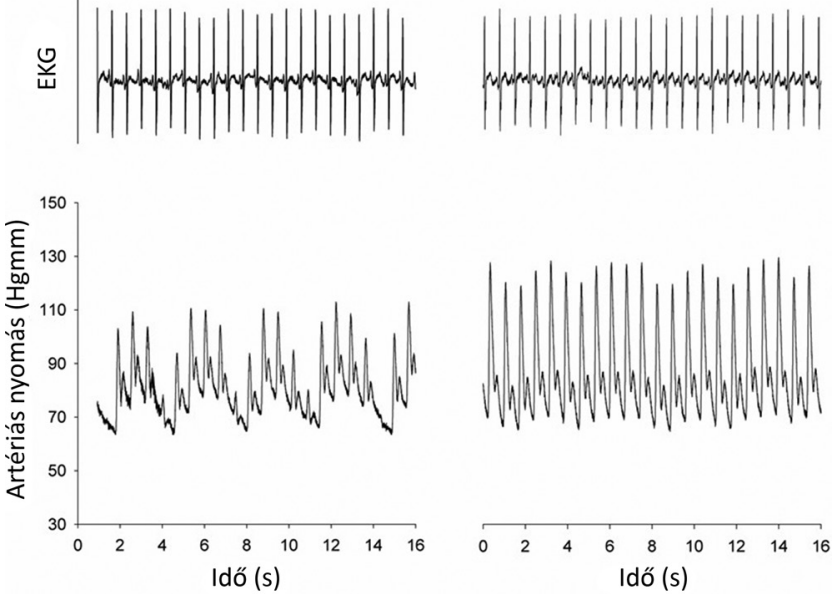

2. ábra

Pericardialis tamponádban szenvedő beteg EKG- és artériásnyomás-felvételei, „A” közvetlenül pericardiocentesis előtt és „B” a beavatkozás után. A systolés nyomás ingadozása alaphelyzetben eléri a $30 \mathrm{Hgmm}$ - $t$, de $10-12 \mathrm{Hgmm}$ ingadozás a pericardialis folyadék lebocsátása után is látható. Feltételezhető, hogy ezt az előző sokkos állapotból még visszamaradó acidosis és a következményes mélyebb légzés okozza

$\mathrm{EKG}=$ elektrokardiográfia

端

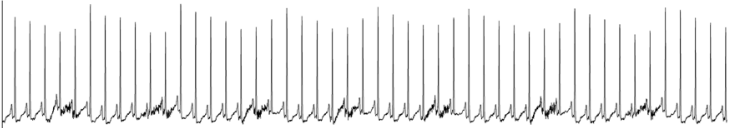

थิ 130

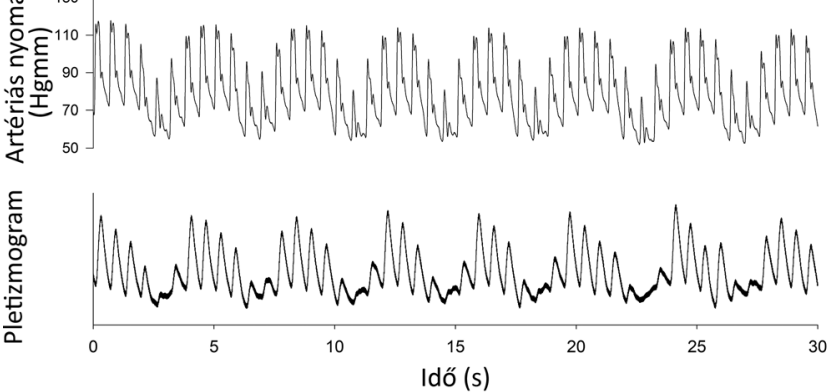

3. ábra

Pericardialis tamponádban szenvedő beteg felvétele. Felhívjuk az olvasó figyelmét az alsó panelen bemutatott fotopletizmogramra. A pulzoximéter a páciens kézujján detektálta a jelet

ki, hogy feszülő pericardium mellett az intrapericardialis tér „fixáltnak” tekinthető, így az egyik kamra fokozott telődése csak a többi szívüreg rovására történhet meg [19]. Ez valójában kórosan fokozott parallel kamrai interdependenciának felel meg. Ezt a gondolatot utóbb számos hemodinamikai és echokardiográfiás vizsgálat támasztotta alá $[10,22-24]$. A másik magyarázat abból indul ki, hogy belégzésben az intrathoracalis nyomás változásának hatására a vénás pulmonalis nyomás a pericardialis nyomás, illetve a bal pitvari nyomás alá esik, és a bal szívfél telődése gátlódik, emellett fokozott pulmonalis vénás raktározás jelentkezik [25]. Bár ezt a mechanizmust cáfoló kutatások is napvilágot láttak [22], a korai bal kamrai diastolés telődés gátlása jól dokumentálható [26]. Jelenleg az mondható, hogy a két vázolt mechanizmus végeredményben nem zárja ki egymást, és feltételezhetjük, hogy mindkét tényező szerepet játszik [20]. Bár az echokardiográfiás leletekre s az általuk megvilágított mechanizmusokra nem tértünk ki, annyit feltétlenül meg kell jegyeznünk, hogy a PP-sal teljesen analóg (s esetenként még korábban észlelhető) jelenség a transvalvularis áramlásoknak vagy az aortaáramlásnak a fokozott oszcillációja - „ezek az áramlási paradoxok” [2], 24]. A 2. és 3. ábra pericardialis tamponáddal észlelt betegekben készült. A tamponád mindkét esetben tumoros infiltráció következtében, időben elhúzódva alakult ki.

\section{A volumenviszonyok szerepe: a soros kapcsolódási effektus késlekedése/ tompulása, illetve e hatás felerősödése}

Amint az előzőekben írtuk, normális körülmények között a belégzésnek a jobb szívfél telődésére gyakorolt hatása néhány szívcikluson belül a bal kamrai verőtérfogatban is jelentkezni fog. Ez a helyzet megváltozik pulmonalis pangásnál, mely a bal kamrai telődés számára tartalékot jelent. Ilyenkor a bal kamra telődése a jobb kamra telődésgátlása ellenére számos szívcikluson keresztül megtartott lehet. Jól illusztrálja a helyzetet az egészséges, illetve szívelégtelenségben szenvedő alanyoknak a Valsalva-manőverre (zárt glottisszal szemben végzett eróltetett kilégzési kísérletre) adott keringési válaszaiban észlelhető különbség (4. ábra) [27].

A volumenhiány épp ellenkezőleg hat. A korábbiakban már kifejtett összetett mechanizmusok révén, Dornhorst korai megfigyelésével teljes összhangban, egészséges alanyokban a volumenvesztés, illetve -átrendeződés (például álló testhelyzet) felerősíti a légzés - különösen a lassú és így szükségszerúen nagyobb légzési térfogattal járó légzés - által kiváltott pulzusamplitúdó-ingadozást [19]. A valódi volumenvesztés nagyon fontos probléma, s kívánatos a korai észlelés. Riegel 1903-ban közölte egy kivérzett beteg esetét, s megállapította, hogy a betegnél észlelt pulzusingadozás megfelelt a PP-nak [28]. Gauchat és Katz 1924-es közleményükben említik, hogy számos esetben figyeltek meg PP-t vérzés, illetve „sebészi sokk" során [18]. Az anekdotikus megfigyeléseket azután Cohn és mtsai állatkísérletes vizsgálattal igazolták altatott, lélegeztetett kutyák kivéreztetése során [29]. A klinikai gyakorlat számára elsőként Coyle és mtsai javasoltak egy, pozitív nyomással lélegeztetett betegekben alkalmazható paramétert, melyet a belégzés során mért maximum és minimum systolés nyomás különbségeként határoztak meg [30]. Tekintettel arra, hogy a spontán és a mechanikus belégzés keringési hatásai ellentétesek, a paramétert „positive pressure paradox”-nak nevezték el [30]. Utóbb Perel és mtsai hasonlóképpen meghatározott paraméterüknek a „systolic pressure variation” (SPV) elnevezést adták, és ez vonult be a klinikai gya- 
A

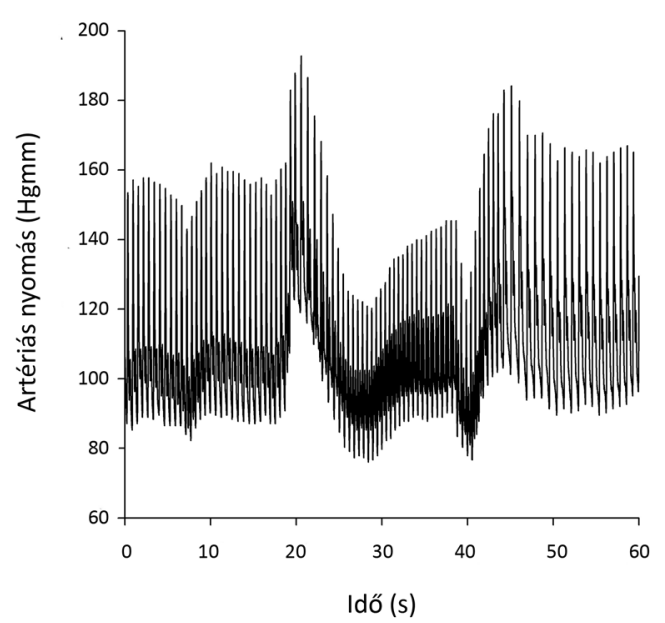

B

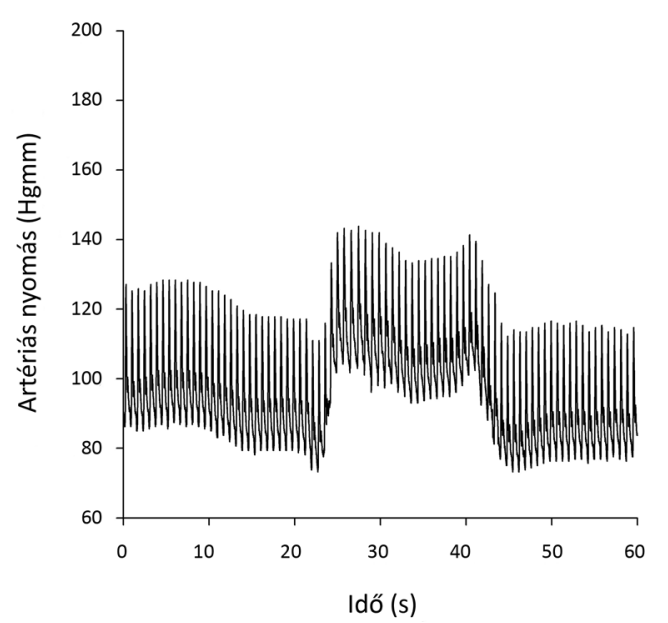

4. ábra

|Zárt hangréssel szemben végzett, 40 Hgmm nyomást 20 másodpercig fenntartó erőltetett kilégzési kísérlet, „A” egészséges önkéntesben és „B” súlyos szívelégtelenségben szenvedő betegben. Az egészséges alanyban a préselés kezdetén jelentkező vérnyomáskiugrást néhány ciklus elteltével ütésről ütésre csökkenő artériás hullámok követik, jelezvén a jobb kamrai telődésgátlás „soros kapcsolódású” következményeit. A szívelégtelen betegnél ez a soros kapcsolódású hatás 20 másodperc alatt sem manifesztálódik

korlatba [31]. Az SPV és a vele analóg pulzusnyomás (PPV)-, illetve verőtérfogat-variabilitás (SVV) napjainkra a lélegeztetett betegek volumenterápiájának fontos meghatározói lettek. E paraméterek és a rajtuk alapuló kezelési stratégiák bemutatása meghaladja jelen összefoglalónk kereteit, a továbbiakban ezeket nem tárgyaljuk. Felhívjuk azonban a figyelmet arra, hogy a jelenség spontán légző betegekben is megfigyelhetö [32], és lassú, vezényelt légzés mellett a hypovolaemia érzékeny indikátora lehet [33]. A megfigyelt jelenség ilyenkor tetszés szerint nevezhető fokozott SPV-nak vagy egyszerúen PP-nak. Az 5. ábra saját vizsgálatunkat szemlélteti, melyben $-60 \mathrm{Hgmm}$ alsótestfél-nyomást alkalmaztunk. A -60 Hgmm-es terhelés >1 liternyi vér akut elvesztésének megfelelő hatást vált ki [34].
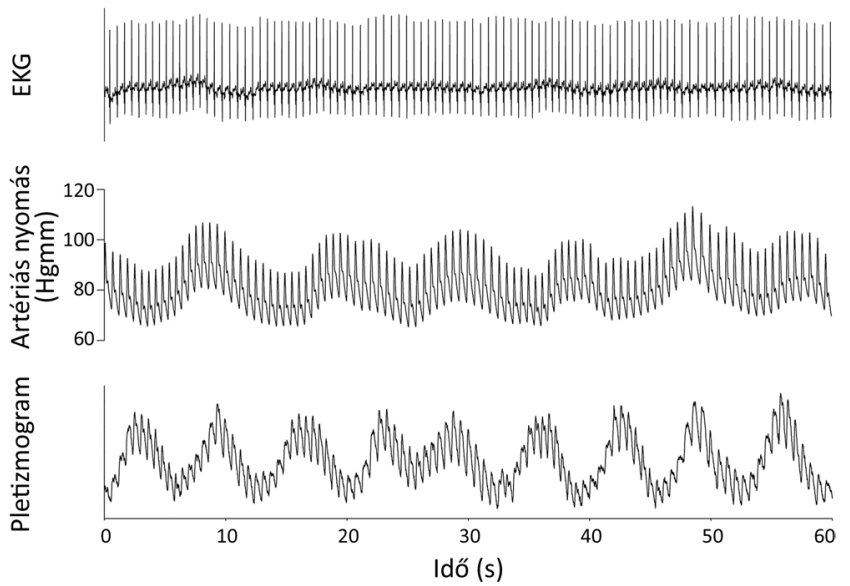

5. ábra

Egészséges önkéntes fiatal férfi vákuumkamrában végzett alsó testfél negatív nyomás tesztje során készült EKG- és artériásnyomás-regisztrátuma, illetve fotopletizmogramja

EKG $=$ elektrokardiográfia
Megjegyzendő, hogy akár spontán légző, akár lélegeztetett betegről legyen szó, a fentiekben leírt egyéb mechanizmusok az intenzív osztályokon fekvő betegeknél is jelentkezhetnek. Ennek megfelelően nyitott mellkasú, kis légzési térfogattal légző, pulmonalis hypertoniában, intraabdominalis nyomásfokozódásban, jobb- vagy balszívfél-elégtelenségben szenvedő betegekben az SPV/ PPV adatok volumenviszonyokat illetó prediktív értéke megváltozik, nem értelmezhetôk [35]. Fontos, hogy a mindennapi gyakorlatban a volumenvesztés mellett a PP fentiekben bemutatott egyéb, ugyancsak életveszélyes okaira is emlékezzünk.

\section{A pseudoparadox pulzus}

A fogalmat Salel és mtsai vezették be 1973-ban. Egy olyan beteg esetét ismertették, akinél pitvar-kamrai diszszociáció és kamrai pacemakerritmus mellett jelentkezett a systolés nyomás fokozott hullámzása [36]. Az, hogy a pitvari kontrakció, bár véletlenszerúen, de a fiziológiás időzítéssel kerül a kamrai kontrakció elé, vagy épp ellenkezőleg, a pitvari és a kamrai kontrakció egyszerre következik be, csökkent kamrafunkciójú alanyoknál számottevően képes modulálni a verőtérfogatot, illetve az artériás nyomást. A 6. ábra egy ilyen esetet szemléltet. A jelenség nem légzésszinkronizált, és nem keverendő össze a valódi PP fentiekben bemutatott formáival [37].

\section{Egy egyszerü diagnosztikus eszköz}

A nagy elődök kifinomult tapintásukra, napjaink intézeti orvosai a modern kor eszközeire, az invazív artériás nyomásra és az ultrahangvizsgálatokra támaszkodva csípik fülön a PP-t. Van azonban egy olyan egyszerú eszköz, 
A

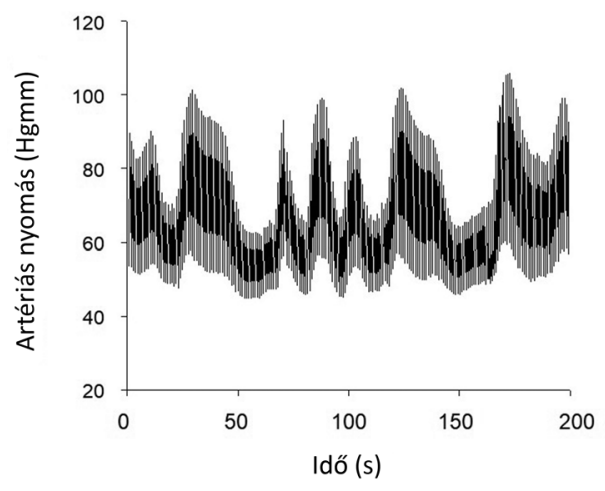

B

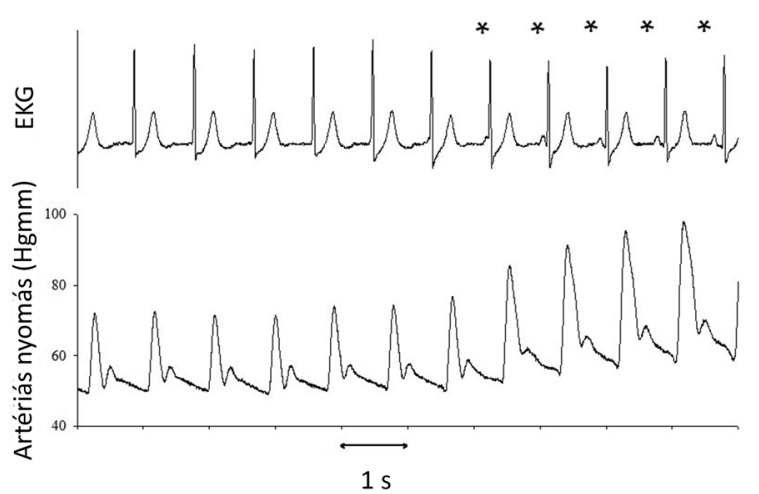

6. ábra Az „A” panel akut hátsó fali szívinfarktusban szenvedő beteg többpercnyi vérnyomás-regisztrátumát mutatja be. A systolés nyomás markáns, irregu-
láris és lassú hullámzása figyelhető meg. A „B” panelen a felvétel kinagyított részlete látható, a hozzá tartozó EKG-szakasz kíséretében. A ritmus ak-
celerált junkcionális ritmusnak felel meg, a független „,p”-hullámok a felvétel második szakaszán bújnak elö, s kerülnek fokozatosan a „R”-hullámok
elé, normális pozícióba (elhelyezkedésüket *-gal jelöltüik). Mindez a systolés nyomás jelentős emelkedéséhez vezet
EKG = elektrokardiográfia

mely a sürgösségi osztályon vagy akár prehospitálisan is felhívhatja figyelmünket a veszélyes helyzetre - ez a pulzoximéter. Az általa generált pletizmogram a vérnyomáshoz hasonlóan extrém fluktuációt mutathat, különböző mechanizmusú PP-ok jelenlétében. Ezt az összefüggést illusztrálja az 1., a 3. és az 5. ábra, s ezeken túl mind az asztmás rohamhoz társuló [38], mind a tamponádot kísérô [39], mind a hypovolaemiát jelző [40] kóros pletizmogramokról irodalmi beszámolók is rendelkezésünkre állnak. Ajánljuk tehát ezeket a megfigyeléseket az első ellátást végző kollégáink figyelmébe!

Anyagi támogatás: A szerzők anyagi támogatásban nem részesültek.

Szerzői munkamegosztás: Z. É.: Az anyag kidolgozása, az illusztrációk készítése, a kézirat szövegezése. R. L.: $\mathrm{Az}$ anyag kidolgozása, szakirodalmi másodelemzés, a végleges kézirat szakmai lektorálása. A cikk végleges változatát amindkét szerző elolvasta és jóváhagyta.

Érdekeltségek: A szerzőknek nincsenek érdekeltségeik.

\section{Irodalom}

[1] Hajar R. The pulse in ancient medicine. Part 1. Heart Views $2018 ; 19: 36-43$.

[2] Ghasemzadeh N, Zafari AM. A brief journey into the history of the arterial pulse. Cardiol Res Pract. 2011; 2011: 164832.

[3] Woo HE, Fung CH. Remarkable physicians associated with pulsus paradoxus, the classic sign - Richard Lower and Adolf Kussmaul. Publication Date: September 2006. Available from: http://www.priory.com/homol/pulsus.htm [accessed: April $27,2020]$.

[4] Kussmaul A. About mediastino-pericarditis and the paradoxical pulse. [Über schwielige Mediastino-Pericarditis und den paradoxen Puls.] Berl Klin Wochenschr. 1873; 10: 433-435; 445449 ; 461-464. [German]
[5」 Bilchick KC, Wise RA. Paradoxical physical findings described by Kussmaul: pulsus paradoxus and Kussmaul's sign. Lancet 2002; 359: 1940-1942.

[6] Sommerbrodt H. Gegen die Lehre vom Pulsus paradoxus. Berl Klin Wochenschr. 1877; 14: 615. [German]

[7] Lewis T. Studies of the relationship between respiration and blood-pressure: part II. Facts bearing on the relationship of different factors in the production of respiratory curves of blood pressure. J Physiol. 1908; 37: 233-255.

[8] Hales S. Statistical essays: containing haemastaticks. Vol 2. Innys, Manby and Woodward, London, 1733.

[9] Dornhorst AC, Howard P, Leathart GL. Respiratory variations in blood pressure. Circulation 1952; 6: 553-558.

[10] Hamzaoui O, Monnet X, Teboul JL. Pulsus paradoxus. Eur Respir J. 2013; 42: 1696-1705.

[11] Bhattacharya M, Kallet RH, Ware LB, et al. Negative-pressure pulmonary edema. Chest 2016; 150: 927-933.

[12] Buda AJ, Pinsky MR, Ingels NB Jr, et al. Effect of intrathoracic pressure on left ventricular performance. N Engl J Med. 1979; 301: 453-459.

[13] Blaustein AS, Risser TA, Weiss JW, et al. Mechanisms of pulsus paradoxus during resistive respiratory loading and asthma. J Am Coll Cardiol. 1986; 8: 529-536. [Correction: J Am Coll Cardiol 1986; 8: 1244.]

[14] Stalcup SA, Mellins RB. Mechanical forces producing pulmonary edema in acute asthma. N Engl J Med. 1977; 297: 592-596.

[15] Jardin F, Farcot JC, Boisante L, et al. Mechanism of paradoxic pulse in bronchial asthma. Circulation 1982; 66: 887-894.

[16] Takata M, Wise RA, Robotham JL. Effects of abdominal pressure on venous return: abdominal vascular zone conditions. J Appl Physiol. 1990; 69: 1961-1972.

[17] Guilleminault C, Tilkian A, Dement WC. The sleep apnea syndromes. Annu Rev Med. 1976; 27: 465-486.

[18] Gauchat HW, Katz LN. Observations on pulsus paradoxus (with special reference to pericardial effusions). I. Clinical. Arch Intern Med. 1924; 33: 350-370.

[19] Dornhorst AC, Howard P, Leathart GL. Pulsus paradoxus. Lancet 1952; 1(6711): 746-748.

[20] Appleton C, Gillam L, Koulogiannis K. Cardiac tamponade. Cardiol Clin. 2017; 35: 525-537.

[21] Meltser H, Kalaria VG. Cardiac tamponade. Catheter Cardiovasc Interv. $2005 ; 64: 245-255$. 
[22] Shabetai R, Fowler NO, Fenton JC, et al. Pulsus paradoxus. J Clin Invest. 1965; 44: 1882-1898.

[23] Settle HP, Adolph RJ, Fowler NO, et al. Echocardiographic study of cardiac tamponade. Circulation 1977; 56: 951-959.

[24] Bodson L, Bouferrache K, Vieillard-Baron A. Cardiac tamponade. Curr Opin Crit Care 2011; 17: 416-424.

[25] Ruskin J, Bache RJ, Rembert JC, et al. Pressure-flow studies in man: effect of respiration on left ventricular stroke volume. Circulation 1973; 48: 79-85.

[26] Kearns MJ, Walley KR. Tamponade. Hemodynamic and echocardiographic diagnosis. Chest 2018; 153: 1266-1275.

[27] Zöllei É, Paprika D, Csillik A, et al. Valsalva maneuver, Müller maneuver: hemodynamic and reflex mechanisms, relevances. [Valsalva-manőver, Müller-manőver: keringési és reflexmechanizmusok, relevanciák.] Orv Hetil. 2007; 148: 343-350. [Hungarian]

[28] Riegel F. About pulsus paradoxus. [Über Pulsus Paradoxus.] Deutsch Med Wochschr. 1903; 29: 345. [German]

[29] Cohn JN, Pinkerson AL, Tristani FE. Mechanism of pulsus paradoxus in clinical shock. J Clin Invest. 1967; 46: 1744-1755.

[30] Coyle JP, Teplick RS, Long MC, et al. Respiratory variations in systemic arterial pressure as an indicator of volume status. Anesthesiology 1983; 59: A53.

[31] Perel A, Pizov R, Cotev S. Systolic blood pressure variation is a sensitive indicator of hypovolemia in ventilated dogs subjected to graded hemorrhage. Anesthesiology 1987; 67: 498-502.

[32] Rooke GA, Schwid HA, Shapira Y. The effect of graded haemorrhage and intravascular volume replacement on systolic pressure variation in humans during mechanical and spontaneous ventilation. Anesth Analg. 1995; 80: 925-932.
[33] Zöllei É, Bertalan V, Németh A, et al. Non-invasive detection of hypovolemia on fluid responsiveness in spontaneously breathing subjects. BMC Anesthesiol. 2013; 13: 40.

[34] Cooke WH, Ryan KL, Convertino VA. Lower body negative pressure as a model to study progression to acute hemorrhagic shock in humans. J Appl Physiol. 2004; 96: 1249-1261.

[35] Fischer MO, Dechanet F, du Cheyron D, et al. Evaluation of the knowledge base of French intensivists and anaesthesiologists as concerns the interpretation of respiratory arterial pulse pressure variation. Anaesth Crit Care Pain Med. 2015; 34: 29-34.

[36] Salel A, Amsterdam EA, Zelis R. Pseudopulsus paradoxus. Chest 1973, 64: 671-672.

[37] Rudas L, Hankovszky P, Lovas A, et al. Cyclic nonrespiratory pulse pressure oscillations caused by atrioventricular dissociation. Case Rep Crit Care 2017; 2017: 7647069.

[38] Hartert TV, Wheeler AP, Sheller JR. Use of pulse oximetry to recognize severity of airflow obstruction in obstructive airway disease. Correlation with pulsus paradoxus. Chest 1999; 115: 475-481.

[39] Tamburro RF, Ring JC, Womback K. Detection of pulsus paradoxus associated with large pericardial effusions in pediatric patients by analysis of the pulse-oximetry waveform. Pediatrics 2002; 109: 673-677.

[40] Murray WB, Foster PA. The peripheral pulse wave: Information overlooked. J Clin Monit. 1996; 12: 365-377.

(Rudas László dr., Szeged, Semmelweis u. 6., 6725 e-mail: rudas.laszlo@med.u-szeged.hu)

\section{"Virtutis omnis impedimentum est timor." (Minden erénynek gátja a félelem.)}

A cikk a Creative Commons Attribution 4.0 International License (https://creativecommons.org/licenses/by/4.0/) feltételei szerint publikált Open Access közlemény, melynek szellemében a cikk bármilyen médiumban szabadon felhasználható, megosztható és újraközölhetö, feltéve, hogy az eredeti szerző és a közlés helye, illetve a CC License linkje és az esetlegesen végrehajtott módositások feltüntetésre kerülnek. (SID_1) 